\title{
The Model Development of Primary School Principal's Competence in Purworejo
}

\author{
Nurtanio Agus Purwanto \\ Department of Educational Management \\ Yogyakarta State University \\ Yogyakarta, Indonesia \\ nurtanio@uny.ac.id
}

\begin{abstract}
The aims of the study were to know: 1) need assessment of education and training for primary school principal and 2) the development of education and training model in improving managerial supervision competence and school principal's supervision. The study used research and development approach where the first stage was implementing the analysis of education and training needs through brainstorming and focus group discussion. Data analysis was done by education and training needs mapping held by primary school principals and training that was needed to improve managerial and supervision competence. The result showed that the needs of education and training for the principals was various that influenced by the principals' education training needs, institution's education training needs, the principals' experience, the commitment of profession organization, and the education level. The problems raised in the field and the school principals' characteristic were also various. Therefore, it needs effective and efficient education and training model in improving the principals' managerial competence and supervision in Purworejo.
\end{abstract}

Keywords—school principals' managerial competence, school principals' supervision competence

\section{INTRODUCTION}

School principal as the leader of the school takes important factor in contributing to an effective school and improvement [1]. The school principals take the role for the students' performance indirectly, they also provide certain vision, mission, and objectives for the school. Institution of school as a central organization where the school principal roles as the leader that should has leadership function [1][2]. School principals should act wise and fair in giving advice to his staff, support the teachers, staffs, and students' need, provide safe environment, appreciate and respect the teachers, staffs, and students. [1] stated that the success of school depends on the school principal's motivation and competence where the principal should have bright understanding of their own practical work, should concern on the students, teachers and school's needs as his main focus. School principal is the leader position that cannot be replaced by people who do not have good education background. A school principal should be determined by specific procedures and requirements, such as: education background, experiences in education, age, position, and integrity that mentioned in the national education ministry policy No. 28, 2010 about the teacher's duty as school principal.
Based on the research implemented by educational employee director in ToT Facilitator of school principal and supervisor at 6 February 2009, the school principal's competences in personality, managerial, supervision, social, and entrepreneurship, especially in managerial and supervision competence were still low. Supervision as internal mechanism adopted by school principal has evaluation and helps the teachers and students in improving teaching and learning activities, so that the education goals achieved well [3]. The school principal also ensures the supervision activity by having interaction among the students and the teachers socially both in the classroom and outside classroom activity[3]. The main purposes of this interaction are monitoring the curriculum implementation to ensure the teachers' competence improved, renewing the conceptual knowledge and teaching competence, supporting the teachers and facilitating the teachers' pedagogic performance and the students' performance.

The supervision in education is used for enhancing the teaching and learning both for the process and its quality [4]. education supervision as a service in order to develop and improve instructional and curriculum function.[4] Education supervision is the school principal's responsibility in guiding teachers and staffs in order to have effective work, have teaching and learning process improvement, and have positive performance of the students[4]. Supervision is the principals' responsibility that simply needs monitoring the school building around and how the things run, having short discussion among the students, visiting class, monitoring information school system, and checking school system performance quality [5].

In managerial competence, [6] adds that managerial competence is specifically related to the management, supervision, and another development, including motivation and strength. The management functions are: 1) planning (budgeting, programming, decision making, forecasting), (b) organizing (structuring, assembling resources, staffing), (c) the mobilization (coordinating, directing, commanding, motivating, leading, motivating), and (d) surveillance (monitoring, evaluating, reporting), [6].

Managerial and supervision problems of school principal are related to many aspects. Those aspects are: 1) knowledge and technology competence, 2) education problem mapping competence, 3) school principal's leadership strategy, 4) 
institution maturity, 5) internal and external cooperation, and 6) another factor situationally and the school characteristic and policy. The development towards the school principals' competence should be done continuously and the correlation where school principal should develop the teachers in order to improve the competence's lack.

\section{PROBLEM FORMULATION}

The problem research is limited by the efforts in providing effective and efficient model in order to improve managerial and supervision competence of school principal. Based on the backgroun of the study, the problem formulation are:

1. What are the education training needs in improving primary school principal's managerial and supervision competence in Purworejo?

2. What is effective and efficient education training model in improving primary school principal's managerial and supervision competence in Purworejo?

\section{RESEARCH AIMS}

Based on the problem formulation above, the aims of the study are to know:

1. The Need Assesment of education and training for primary school principal

2. The development of education and training model in improving managerial supervision competence and school principal's supervision

\section{LITERATURE REVIEW}

\section{A. School Principal}

According to National Education Ministry of Indonesia mentioned in [7], school principal is the most important of education components in order to enhance education quality. Generally, school principal is responsible for the management of educational activities, school facilities, school administration, and educators. [8] states that school principal should have ability in collaborating among knowledge, energy, and his professional competence and motivating other staffs to transform the school atmosphere and environment to prepare students graduate well and ready to have a job. [8] also adds that in order to be an effective instructional leader, school principal should aware the differences of the students' culture and learning needs, make a wise decision based on how he can help the students success, recognize the system in the students' performance, and responsible for the students' learning.

[9] mention the school principal's roles in general that can be divided into 5 aspects: academic role, motivation role, supervision role, leadership role, and managerial role. They add that generally, school principal plan and prepare the students' future, try to achieve the standards among staffs and students, monitor the school policy's functions, give advices for the staffs to have competence professionalism, establish positive and cooperative relation among the staffs, parents, teachers, and environments, and be a role model for the staffs, teachers, and students.

In addition, [10] also mentions that school principal takes a role model in: 1) ensuring the time, fund, and professional development sources are in line with the instructional purposes, 2) supporting the teacher's professionalism growth in various ways; 3 ) including the teacher in information development; 4) being a bridge between the relation among school and community; 5) and maintaining daily tasks in managing the school. Those roles can be seen as daily or weekly tasks in order to accomplish problems arose among school, community, and environment.

School leader has 3 main functions in influencing the purpose and policy's development, establishing and coordinating education with planning and implementation program, and maintaining the sources in order to support the educational system [11]. Interstate School Leaders Licensure Consortium (ISSLC) in [1] classified the functions of school principal as: 1) determine the vision with school stakeholders, 2) establish the culture and school instructional program for the professional growth of the students and staffs, 3) ensure that school management runs effectively, efficiently and conductively, 4) cooperate and respond to the needs of staff and community, 5) have integrity and ethical, and 6) recognize and respond to political, social, legal, and cultural context diversity.

The Commonwealth Secretariat in [12] add the school principal's functions and roles as: 1) maintaining school resources efficiently, 2) allocating school accommodation appropriately, 3) ensuring the school standards and facilities, 4) managing staff development, 5) guiding the curriculum implementation, 6) establishing a professional ethos by involving staff members and teachers in decision making, and 7) maintaining school system development both evaluation and integrated quality of management system. School principal takes role in various responsibilities, policy, rules and regulations' decisions making, and also ensures productive teaching-learning environment. School principal duty is also quite challenging and demanding, especially in the effectiveness of educational and institutional development [9]. School principal that has those requirements mentioned above is expected to be able to take the school and institution's success and its educational quality.

\section{B. Managerial Competence of School Principal}

Gibson in [2] defines competency as a trait mentally or physically that be learned by someone to do something. Boulter et al. in [2] adds the definition of competence as someone's fundamental characteristic to do his performance job. Meanwhile, Armstrong in Rahardjo adds that competence is the skill, knowledge, and someone's quality in order to achieve his work success.

In addition, Bartman et al. in [1] reveals that competency is knowledge, attitudes and skills of individual to accomplish his job and solve problems efficiently and effectively. 
Competence is the basic foundation of someone's characteristics that indicates how he behaves and thinks, encourages and support the situation based on his skills and knowledge and performance or behavior at work (Spencer, Zwell, and Wibowo in [6]. According to Sagala and Mudlofir in [4], competence is human characteristic and competent including skills, power, ability, authority, and knowledge reflected in the daily habitual action. Meanwhile, the competence principles according to Ministry of National Education of Indonesia 2007 mentioned in [1] are personal, management, entrepreneurship, supervision, and social competence principle. In supervision competence, school principal design, monitor, then evaluate the academic program supervision.

Meanwhile, in managerial competence of school principal based on Sudrajat opinion in [6], school principal has ability in:

1) planning school program and school development both short term and long term, renewing operational design development based on the appropriate principles, and managing school funding.

2) mastering theory and policy of national education in school institution management

3) being a good leader for the teachers and staffs in utilizing human resources accurately.

[1] adds that there are 3 important things that should be considered by school principal as a manager:

1) process which is systematically way in doing a work

2) school resources including funding, facilities, information, and human resources that used to be a thinker, designer, and supporter to achieve the desire purposes

3) achieve organization objectives that has been set.

School principal's managerial competence according to Ministry regulation of national education No. 13, 2007 about school principal standards, are as below.

1) arranging school planning for various planning stage

2) developing school organization based on the needs

3) maintaining the transformation and development of school to be an effective learning organization

4) managing the school facilities optimally

5) maintaining the relationship among school and community

6) managing the students' place and capacity development

7) managing the curriculum development and teaching and learning activities based on national education objectives

8) managing school administration in supporting school activities
9) Managing special service unit of the school

10) Applying entrepreneurship principles in creating school development innovation

11) Creating conducive work culture and atmosphere for the students' learning

12) Managing school information system in supporting program arrangement and decision making

13) Utilizing technology information improvement in order to enhance school learning and management

14) Maintaining the production or service activities in order to support school funding resources and the students learning resources.

\section{Conceptual Competence}

Drake and Roe in [1] explain five competencies of principal as the educational leader: conceptual skills, human skills, instructional skills, technical skills and cognitive skills. Meanwhile, Katz in [1] divides the three skills include: technical skills, human skills, and conceptual skills.

[5] defines conceptual skills as the school principal's mental ability to see and assess a whole aspects of organization and solve problems in order to achieve the expected goals and objectives, which are ability in obtaining, analyzing, and interpreting the information and making complex decision to achieve the school objectives. The conceptual skills needed by school principal are ability in anticipating the changes or maintaining school strategy values. The responsibilities in supervision aspect are being a decision maker, resources allocator, and have good perspectives.

School principal also has to develop conceptual skills in order to think strategically for long term [5]. It makes school principal recognize how his environment work is and serve reflective situation [5]. [5] adds that school principal should consider the environment pressure, parents' complaint, staff administration talent, education policy, resources development, and organization transformation as significant advices for school internal environment.

From those notions above, it can be said that how important conceptual skill is for school principal as education manager to accomplish his managerial responsibility, include planning, organizing, policy determining, problem solving, and developing effective program effectively. Human skill also should be considered by principal due to the school activities is also human activities among school principal, teachers, students, and staffs in order to achieve educational purposes.

\section{Technical Duty of School Principal}

According to Locke in [5], technical competence is an ability in using knowledge, method and technique from specific discipline. [5] also states that school principal is a role model that has technical competence, which is as an expert at his own discipline and has ability in monitoring people. In 
order to achieve the successful education department program, principal should recognize how to teach subject, manage group, obtain resources, evaluate the performance, and so on. [9] explain a success school principal is principal that should: 1) understanding the future work (leadership function); 2) understanding needed attitude (administrative role); and 3) mastering the ability in doing his work (management skills). In education field, technical skill is the ability of principal in recognizing and using knowledge, funding, reporting, scheduling, and caring method.

\section{RELEVANT STUDY}

A. Mustamin, Yasin MA. (2012). The Competence of School Principals: What Kind of Need Competence for School Success?. Journal of Education and Learning. Vol.6 No. 1. pp. 33-42

[1] explains the type of school principal's competence in making decision through problems arose in order to achieve the school success. In order to have a successful planning for school, he principal should "school oriented" generally, teacher and staff oriented and the students' learning performance oriented. Meanwhile, the competence that relates to the school is leadership competence, including teaching leadership competence that based on the responsibility for teachers and staffs and operational leadership competence that oriented to the students' performance.

B. Lunenburg, Fred C. 2010. The Principal and the School: What Do Principals Do?. National Forum of Educational Administration and Supervision Journal. Volume 27, Number 4

[5] divided 3 main characteristics in the school principal's role, including:

1. The principal's performance towards his duty

2. The principal's various activities

3. School principal that has good ability in communication aurally.

In order to implement its functions and roles, school principal needs 3 kinds of skills: conceptual, human, and technical skill. Conceptual skill is more important in school hierarchy level, while technical skill is the most critical in supervision field and human skill is also important for the whole levels. His study showed that the school principal's failure was influenced by his un-ability in the terms of communication. In managerial competence, school principal may create policy, rules, procedures, and authority relationship. In addition, school principal should be able to establish norms in order to build culture foundation for the school success.
C. Yasin, M., Mustamin \& Tahir, LM. 2013. Principal Competencies and the Achievement of National Education Standard in Indonesia. International Journal of Humanities and Social Science Invention. Volume 2, Issue 8. pp.31-36

[1] research showed that the score of Indonesia national education standard level and school principals' competency level were high. The analysis used the Structural Equation Modelling (SEM). The results of their study showed that there were significant relationships between the competency levels of school principals and the achievement of the national education standard of Indonesia (SNP). The score of respondents for the SNP standard of the schools' achievement were also high. Regarding to the school principal's leadership and instructional skill had direct impact on the achievement of SNP standard.

\section{METHOD}

The research was done by providing development model of school principal's competence improvement in purpose. Based on this purpose, this research is Research and Development. The steps in designing this development model are:

1) Data collection by doing observation

2) Data collection by brainstorming and Focus Group Discussion to the respondenrts.

3) Reviewing education and training model of school principals in Purworejo

4) Identifying the problems and requirements of improvement model

5) Finding the solutions

In reviewing education and training model of school principal, it will give recognition towards the newest procedures of the model designed by the researchers. The education and training funtions of the research are identifying the problems and requirements of principals' education and training and finding its solutions. By recognizing the limitations and functions of this model, the researchers developed new model development of education and training of the school principals in Purworejo.

The researchers collected the qualitative data by expalining in description of words and sentences. The data were related to the model of primary school principal's competence in Purworejo of Central Java, involved parties, and human resources that supported this education and training. According to Creswell (2003: 185), the data collection procedures are observation, interviews, documentation, and audio and visual material. The data collection method of this study used observation, interview, document collection, and audio visual data collection.

The data needed to be reduced, summarized, chosen, found the theme and it pattern. Through reduction process, it 
was expected to provide sharp pictures about the research result and certain aspects that was for the research focus. The data reduction of analysis data process should be done and important.

The data served in the form of narrative that should be summarized in order to simplify the data and information collection. On the other hand, the conclusion was taken by the data presentation that needed to find the theme, pattern, similarity, comparison, etc. Data reduction, data presentation, and conclusion are the part of data analysis of the research. Based on the conclusion of the research, it can be formulated new model for the development of school principals' competence that can be applied by other regions.

\section{RESULTS AND DISCUSSION}

\section{A. RESULT}

The research was held at April to November 2013. Purworejo is located $65 \mathrm{~km}$ from Yogyakarta and it is at the west side of Kulon Progo. The research was done by analysis of regency, primary schools and the school principals' analysis in Purworejo. There are 524 primary schools that spread equally in the city that was about $25 \%$ from the entire of Purworejo. The implementation of brainstorming and Focus Group Discussion (FGD) was held in August 2013. Before this implementation, the researchers also had discussion and coordination with education and culture department chief, Secretary Official, the chief of primary school field, and Koordinator Musyawarah Kerja Kepala Sekolah (MKKS) of Purworejo.

Needs Analysis and Education Training Model in Primary School Level

Based on the result of Focus Group Discussion (FGD) among primary school principals in Purworejo, it can be explained that the problems faced by the principals in managerial competence were various. Those problems were:

a. Management administration

b. School principal's management

c. Funding management

d. Technology information development

e. Teacher's performance evaluation

f. Leadership

g. School funding plan (RAPBS); school evaluation (EDS); school plan (RKS)

h. School action research (PTS)

In the needs of managerial competence, school principals expected to have special education and training for principals that includes all of those problems mentioned above, by combining among theory, practice, and benchmarking of managerial. Meanwhile, based on the needs analysis of education and training in supervision competence of primary school principal, it was found some problems in:

a. Supervision administration

b. Leadership

c. Supervision technic

d. Supervision format

e. Supervision learning

\section{f. Academic supervision}

Primary school principal expected to have education and training for supervision competence through theoretical and practical supervision, and field study supervision. The needs analysis of education and training in primary school level were also various due to the related principals.

Based on the analysis above, it can be explained that both supervision and managerial competence problems of primary school principals were leadership aspect which was as the basic problem faced by primary school principals. The school principals expected to have certain and special education and training for leadership competence as the efforts of managerial and supervision competence.

\section{B. DISCUSSION}

Based on the research result, both interview and intensive discussion, brainstorming and Focus Group Discussion among education department party and school principals, it shown that primary school principals need various training adapted with principal's experiences and individual factors. The age of the principals influences their motivation and performance in mapping education training needs time by time.

The needs of education and training are influenced by the principals' experiences, year of service, organization existences such as MKKS, principals' forum, and the like. The education department's role has been not optimal yet due to limited funding and priority job program. There was also no training feedback so that there was no continued communication. It impacted with the principal's performance improvement after training. On the other hand, education department's role in funding allocation has also been not optimal yet in order to help the school principal's competence improvement.

Based on the discussion above, the researchers develop prototype model of training that expected to be able to solve both school principals' problems and education department or involved institution. The prototype model of principal competence in education and training is as below. 


\section{DIAGRAM I}

PROTOTYPE MODEL OF PRINCIPAL COMPETENCE IN EDUCATION AND TRAINING

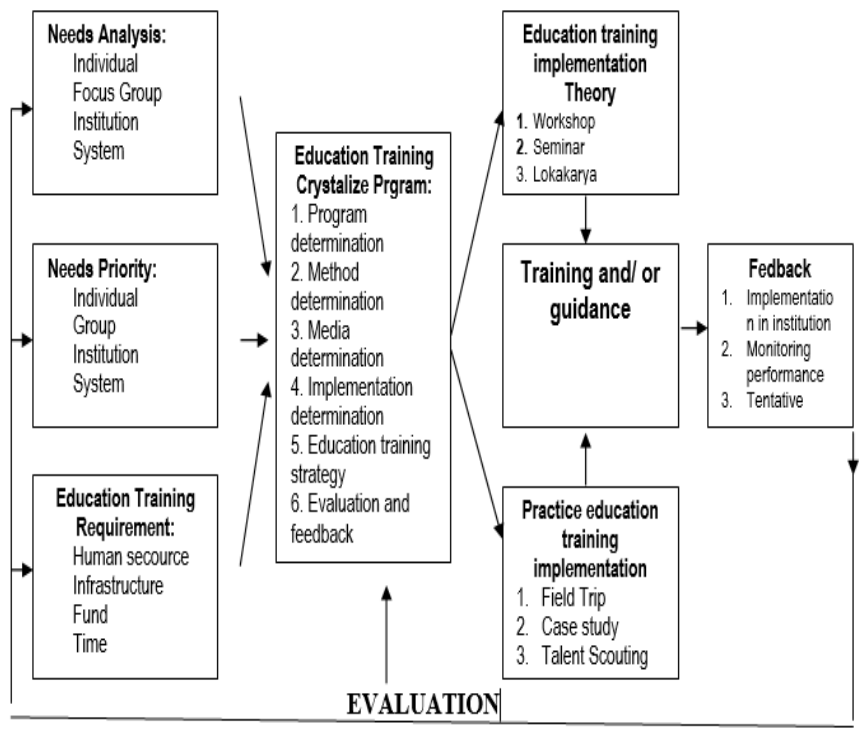

At the second year of this research, it was held the next step of the research, which were:

1. Validation of prototype model development by the expert towards the first school principal's competence improvement that consulted by party that had pra-principal competence

2. Education and training program arrangement based on the needs analysis

3. The implementation of school principal competence development based on the material and human reseources

4. The implementation of education and training result in school.

Based on the implementation, it has been developed the implementation model of school principal's competence development and dissemination towards another school principal.

\section{VIII.CONCLUSION}

Based on the result and discussion of the study, it can be concluded that:

1) Education training needs in managerial and supervision competence improvement in Purworejo were various that influenced by:
a. Education training needs of each school principals
b. Education training of institution
c. School principals' experiences
d. Commitment of profession organization
e. Education level

2) An effective and efficient education and training model to improve the school principals' managerial and supervision competence improvement in Purworejo needs:
a. Needs analysis
b. Education training priority identification
c. Education training requirements
d. Education training determination
e. Integrated education training
f. Training and guidance
g. Evaluation and feedback
h. Evaluasi dan tindak lanjut

\section{ACKNOWLEDGMENT}

This research is expected to give contribution for education and training needs, the existence of profession organization such as MKKS, school principals' forum, education department, primary school principals in Purworejo. The researchers also would like to thank some parties that involved in this research, where it can be utilized in developing competence model of the school principals' improvement in Purworejo.

\section{REFERENCES}

[1] Yasin, M., Mustamin \& Tahir, LM. 2013. Principal Competencies and the Achievement of National Education Standard in Indonesia. International Journal of Humanities and Social Science Invention. Volume 2, Issue 8. pp.31-36

[2] Rahardjo, Sri. 2014. The effect of competence, leadership and work environment towards motivation and its impact on the performance of teacher of elementary school in Surakarta city, Central Java, Indonesia. International Journal of Advanced Research in Management and Social Sciences. Vol. 3 No. 6. pp 59-74

[3] Ayeni, Adeolu J. 2012. Assessment of Principals‘ Supervisory Roles for Quality Assurance In Secondary Schools in Ondo State, Nigeria. World Journal of Education. Vol. 2, No. 1. Pp. 62-69

[4] Idris, Muhammad. The Impact of Supervision, Motivation and Work Ethic on Teachers' Professional Competence: A Case Study of Private Islamic High School Teachers. International Journal of Human Resource Studies. Vol. 6, No. 1

[5] Lunenburg, Fred C. 2010. The Principal and the School: What Do Principals Do?. National Forum of Educational Administration and Supervision Journal. Volume 27, Number 4

[6] Alius, Hamzah, Kompri, Dr. Alius et al., M.Pd.I. 2013. The Effect of Principal Managerial Competence in Developing Cultural Organization and Job Satisfaction MTs Teacher in Jambi. International Journal of Science and Research. Volume 5 Issue 8

[7] Mustamin, Yasin MA. (2012). The Competence of School Principals: What Kind of Need Competence for School Success?. Journal of Education and Learning. Vol.6 No. 1. pp. 33-42

[8] Council of Chief State School Officers. (2015). Model Principal Supervisor Professional Standards 2015. Washington, DC: CCSSO 
[9] Khan, A Naseeb \& Khan, IA. 2014. Academic Role of a Principal and Continuous Professional Development. Journal of Education and Human Development. Vol. 3, No. 2. pp. 925-942

[10] Lunenburg, Fred C. 2010. The Management Function of Principals. National Forum of Educational Administration and Supervision Journal. Volume 27, Number 4

[11] Ibukun, W.O., et al. 2011. Personality characteristics and principal leadership effectiveness in ekiti state, Nigeria. International Journal of Leadership Studies. Vol. 6 Iss. 2. Pp. 247-262

[12] Amuche, CI \& Saleh, DA. 2013. Principals Managerial Competence as A Correlate Of Students' Academic Performance In Ecwa Secondary Schools In North Central Nigeria. Journal of Education and Practice. Vol.4, No.4 